\title{
ANALISIS PERKEMBANGAN KOGNITIF SISWA PADA PEMAHAMAN KONSEP MATEMATIKA KELAS V SDN MAGUWOHARJO 1 YOGYAKARTA
}

\author{
Triwahyu Riyatuljannah ${ }^{1}$, Suyadi $^{2}$ \\ Universitas Islam Negeri Sunan Kalijaga Yogyakarta
}

\begin{abstract}
Cognitive delvelopment is non-physical development. The purpose of this study is to analyze the development of cognitive learning and mathematics learning and student learning in mathematics learning. These study uses a qualitative approach and is carried out in class V, amounting to 27 students of Maguwoharjo 1 Elementary School, Depok Distric, Sleman Regency, Yogyakarta and uses test and interview techniques. The test used in these study is in the form of student worksheets. Interviews are used to get data and information understanding students' mathematical concepts from the classroom teacher. The result of these study are completeness indicators of understanding concepts thas are not equally distributed and have not yet mastered indicators of understanding mathematical concepts. The results of the analysis state that elementary age students who master indicators of understanding mathematical concepts are better at cognitive development than other students because indicators of understanding mathematical concepts are individual representations of students on cognitive development.
\end{abstract}

Keyword: cognitive development,understanding of mathematical concepts

\begin{abstract}
Abstrak: Perkembangan kognitif adalah perkembangan komprehensif yang sifatnya nonfisik. Tujuan dari penelitian ini adalah untuk menganalisis hubungan perkembangan kognitif dan pembelajaran matematika serta mengetahui kendala siswa usia sekolah dasar dalam pemahaman konsep pada pembelajaran matematika. Penelitian ini menggunakan pendekatan kualitatif dan dilaksanakan di kelas V yang berjumlah 27 siswa SD Negeri Maguwoharjo 1 Kecamatan Depok Kabupaten Sleman Yogyakarta dan menggunakan teknik tes dan wawancara. Tes yang digunakan dalam penelitian ini adalah berupa LKS (Lembar Kerja Siswa). Wawancara digunakan untuk mendapatkan data dan informasi pemahaman konsep matematika siswa dari guru kelas. Hasil penelitian ini adalah ketuntasan indikator pemahaman konsep yang tidak sama rata dan belum menguasai indikator pemahaman konsep matematika. Hasil analisis menyatakan bahwa siswa usia dasar yang menguasai indikator pemahaman konsep matematika lebih baik pada perkembangan kognitifnya dibandingkan siswa lainnya karena indikator pemahaman konsep matematika adalah gambaran individu siswa pada perkembangan kognitif.
\end{abstract}

Kata Kunci: Perkembangan kognitif, pemahaman konsep matematika

\section{PENDAHULUAN}

Manusia merupakan makhluk hidup yang dapat berperan sebagai objek dan subjek. Karena manusia adalah makhluk yang menarik serta memiliki tingkatan yang paling tinggi diantara makhluk hidup lainnya di muka bumi. Manusia sebagai makhluk hidup yang senantiasa membutuhkan orang lain untuk berinteraksi dan saling membantu satu sama lain. Adanya interaksi antar individu dengan individu, individu dengan kelompok maupun kelompok dengan kelompok.

Manusia hidup dalam lingkungan bermasyarakat yang artinya memiliki pengaruh pada perkembangan dan pertumbuhan manusia yang dimulai dari masa pranatal hingga di akhir hidupnya.

'UIN Sunan Kalijaga Yogyakarta, Email: triwahyuriatuljanah @gmail.com

2UIN Sunan Kalijaga Yogyakarta, Email: suyadi国uin-suka.ac.id 
Pertumbuhan dan perkembangan manusia meliputi segala aspek yang terbagi dua yaitu fisik dan non-fisik. Perkembangan dari segi aspek fisik manusia yaitu perkembangan tinggi badan, berat badan, motorik (otot dan syaraf) dan otak, sedangkan perkembangan non-fisik manusia meliputi perkembangan kognitif, sosio-emosional dan bahasa. Perkembangan dari segi fisik dan non-fisik manusia tentu berbeda dengan individu yang lainnya. Perkembangan salah satu individu bisa saja lebih cepat dan lebih baik dibandingkan dengan individu yang satunya. Perbedaan tersebut diakibatkan dari faktor usia, makanan, lingkungan dan genetika (Bujuri, 2018).

Menurut Woolfolk (1995), fungsi otak dibagi menjadi dua bagian dari kedua otak manusia, yaitu belahan otak kiri dan belahan otak kanan. Otak kiri memiliki fungsi kemampuan berpikir analitis, rasional, ilmiah, logis, konvergen, dan kritis. Kegiatan yang berkaitan pada otak kiri adalah kemampuan membaca, belajar menghitung, belajar bahasa dan bereksperimen. Bagian otak kanan memiliki fungsi berpikir imajinatif, divergen, intuitif dan holistik. Kegiatan yang berkaitan dengan otak kanan yaitu melukis, bermusik, handmade dan kegiatan seni yang lainnya.

Otak manusia mengalami perkembangan dan pertumbuhan yang sesuai dengan tahapan usianya. Piaget menjelaskan tahap perkembangan kognitif didasarkan usia yaitu: motor-sensory 0-2 tahun, pre-operational 2-7 tahun, concrete operational 7-12 tahun dan formal operational 12 tahun (Latifa, 2017).

Pengetahuan perkembangan manusia penting diketahui dan dipahami sebagai kebutuhan dan karakter manusia terutama pada anak usia dasar yang berada dalam rentang usia 7-12 tahun, dalam pendidikan berarti usia ini adalah usia dalam masa pendidikan sekolah dasar. Memahami perkembangan siswa usia dasar sudah menjadi tugas pokok bagi kedua orang tuanya di rumah, guru di sekolah dan orang dewasa di lingkungan siswa tinggal. Sesuai dengan pendapat Hurlock (Rakhmawati, 2015) bahwa orang tua memiliki peran penting bagi perkembangan anak, selain itu guru dan teman sebaya juga berpengaruh pada sisi psikologisnya. Anak akan berkembang baik dengan mengenal hal positif dan negatif dari apa yang dipelajarinya. Keberadaan orang tua lebih penting karena keluarga adalah bagian utama pada pembentukan karakter anak

Maka anak atau siswa pada usia dasar perlu diasuh oleh orangtua dengan hal-hal yang baik seperti agama, disiplin, jujur, tolong menolong dan sebagainya. Menimbang anak pada usia dasar belum sepenuhnya matang dan dapat berpikir jangka panjang, keterbatasan pada anak belum maksimal dalam memilih baik dan buruk. Maka aspek yang paling penting untuk mengetahui dan memahami perkembangan komprehensif yaitu berpikir, nalar, mengingat, dapat memecahkan masalah, terampil serta kreatif. Perkembangan kognitif memberikan pengaruh yang besar sehingga dapat menjadi kunci dari seluruh perkembangan yang sifatnya non-fisik.

Proses pembelajaran di SD/MI tidak terlepas dari aspek kognitif sebagai pedoman kegiatan belajar hingga penilaian. Pemahaman perkembangan kognitif siswa usia dasar dalam proses pendidikan akan maksimal apabila bahan ajar yang disampaikan dapat dipahami oleh siswa. Realitanya masih terdapat penyampaian materi dengan aspek kognitif secara personal di luar jam pembelajaran. Akibatnya proses pembelajaran tidak sesuai dengan perencanaan pembelajaran, terutama pemahaman konsep matematika, perlu ketekunan dan ketelitian untuk mengoperasikan angka dan simbolnya.

Matematika sebagai ilmu murni dengan menggunakan bermacam-macam angka dan simbol serta hubungan antara bilangan dan prosedur operasi yang mencakup penjumlahan, pengurangan, pembagian dan perkalian. Sujono (Fathani, 2009) mengatakan bahwa "Matematika 
merupakan ilmu pengetahuan tentang penalaran yang logic dan sebagai ilmu bantu dalam mengiterpretasikan berbagai ide dan kesimpulan". Begitupun dengan Suriasumantri yang menyatakan bahwa Matematika merupakan bahasa yang melambangkan serangkaian makna dan pernyataan yang ingin kita sampaikan. Lambang matematika bersifat artifisial, artinya setelah sebuah makna diberikan padanya. Tanpa itu maka matematika hanya sekumpulan rumus-rumus mati (Astuti, 2012).

Aktivitas siswa dalam pembelajaran matematika hanya menghafalkan rumus ataupun konsep dan terkadang tidak melihat keadaan sebenarnya yang relevan dengan konsep matematika yang ada di buku. Kondisi ini membuat indikator pada pemahaman konsep siswa di bawah ratarata. Pemahaman konsep ialah kapabilitas yang harus dimiliki siswa saat menerapkan algoritma yang tidak kaku, cermat, efisien dan pas (Lestari, 2018). Susanto mengatakan pemahaman konsep matematika adalah kemampuan yang mampu menjelaskan keadaan menggunakan kalimat yang beragam dan bisa menyimpulkan dari data, grafik, tabel dan lain-lain (Fahrudin, Zuliana, \& Bintoro, 2018).

Hubungan antara matematika dengan perkembangan kognitif adalah hal yang signifikan, matematika memberikan dampak berarti bagi berkembangnya kognitif seseorang. Seperti yang telah diteliti sebelumnya oleh Hidayati (2012) bahwa jika matematika menjadi hal yang digemari oleh siswa usia dasar maka akan menjadi sesuatu yang sifatnya konkrit dan menarik sehingga siswa tidak mengalami kesulitan yang lebih tinggi lagi dalam belajar matematika.

Matematika merupakan mata pelajaran yang perlu dan wajib diajarkan di jenjang SD/MI, jika tidak disampaikan dalam pembelajaran akan berakibat fatal pada diri siswa karena semua jenjang pendidikan tidak luput dari pelajaran eksak matematika ini. Bahkan dalam menjalankan kehidupan sehari-hari tidak pernah lepas dari nilai matematika. Penerapan nilai matematika biasa digunakan di rumah, kantor, sekolah dan lingkungan masyarakat. Matematika sebagai nilai kehidupan anak usia dasar akan memberikan dampak perkembangan kognitif yang baik.

\section{METODOLOGI PENELITIAN}

Pelaksanaan penelitian ini menggunakan pendekatan kualitatif, penelitian kualitatif ini dilaksanakan berdasarkan indikator kemampuan pemahaman matematika. Indikator pemahaman matematika yaitu : (1) Menyatakan ulang sebuah konsep, (2) Mengklasifikasikan objek sesuai dengan sifat tertentu sebagai konsepnya, (3) Memberi contoh dan bukan contoh dari suatu konsep, (4) Menyajikan konsep dalam berbagai bentuk representasi matematis, (5) Mengembangkan syarat perlu atau syarat cukup dari suatu konsep, (6) Menggunakan dan memanfaatkan serta memilih prosedur atau operasu tertentu dan (7) Mengaplikasikan konsep algoritma pada pemecahan masalah. Populasi pada penelitian ini adalah siswa SD Negeri Maguwoharjo 1 Yogyakarta. Sampel pada penelitian ini adalah bagian dari populasi pada penelitian ini yaitu siswa kelas $\mathrm{V}$ usia 10-11 tahun dengan jumlah 27 orang siswa yang terdiri atas 11 siswa laki-laki dan 16 siswa perempuan. Teknik pengambilan sampel pada penelitian ini menggunakan teknik purposive sampling, instrumen yang digunakan adalah tes dan wawancara dengan tujuan untuk memperoleh hasil belajar dan data informasi siswa dari guru pada mata pelajaran matematika..

\section{HASIL PENELITIAN DAN PEMBAHASAN}

Perkembangan kognitif merupakan aspek terpenting dalam sebuah acuan proses pendidikan. Ranah kognitif adalah ranah yang memiliki kaitanya dengan tujuan dan hasil belajar yang berorientasi pada kemampuan berpikir dikenal dengan 
istilah ranah kognitif Taksonomi Bloom. Ada enam tingkatan dalam Taksonomi Bloom sebagai berikut: mengingat (C1), memahami (C2), menerapkan (C3), menganalisis (C4), mengevaluasi (C5) dan mencipatakan (C6) (Gunawan \& Palupi, 2017). Tingkatan ranah kognitif memahami diterapkan dalam pemahaman konsep, memberikan contoh, menyajikan konsep, memberikan contoh, menyajikan konsep, mengaitkan berbagai konsep dan mengembangkan konsep.

Perkembangan ranah kognitif merupakan hal yang sangat penting untuk mengetahui seseorang dalam kemajuannya berpikir dan mampu menilai diri serta lingkungannya. Whitfield mengatakan bahwa perkembangan kognitif seseorang banyak dipengaruhi oleh beberapa faktor yang substansial yang berasal dari daya ingat, pengetahuan dan penalaran induktif (Prabowo \& Widodo, 2018). Penyelenggara pendidikan sangat erat kaitannya terhadap perkembangan kognitif terutama dalam kegiatan belajar mengajar. Belajar matematika dirasa sulit bagi sebagian siswa dalam memahami, memaknai dan menyelesaikan soal, sehingga menyebabkan perkembangan kognitif tidak berkembang secara optimal sesuai dengan fase usia dasarnya.

Data yang didapatkan menggunakan instrumen wawancara kepada guru dan siswa pada siswa berupa soal uraian matematika yang berjumlah 8 soal materi matematika. Wawancara yang dilakukan kepada guru dan siswa merupakan wawancara terstruktur berdasarkan indikator pemahaman konsep matematika. Ada beberapa siswa yang belum mencapai standar KKM yaitu 70 , ditemukan 12 dari 27 siswa yang meraih nilai standar KKM. Hal ini dikarenakan kemampuan prasyarat yang tidak dimiliki siswa. Penguasaan materi prasyarat merupakan tanda kesiapan siswa dalam mengikuti pelajaran materi matematika selanjutnya. Konsep lanjutan yang sulit dipahami sebelum memahami dengan baik konsep sebelumnya menjadi prasyarat (Putri, Nursalam, \& Sulasteri, 2014). Hasil kemampuan pemahaman pada pembelajaran matematika dapat dilihat pada Tabel 1 di bawah ini.

Tabel 1. Hasil Kemampuan Pemahaman Matematika Siswa

\begin{tabular}{llll}
\hline No & Indikator & Persentase (\%) & Rata-rata \\
\hline 1 & Menyatakan ulang sebuah konsep & $50 \%$ & \\
2 & $\begin{array}{l}\text { Mengklasifikasikan objek sesuai dengan sifat } \\
\text { tertentu sebagai konsepnya }\end{array}$ & $65 \%$ & \\
3 & $\begin{array}{l}\text { Memberi contoh dan bukan contoh dari suatu } \\
\text { konsep }\end{array}$ & $60 \%$ & $40,71 \%$ \\
4 & $\begin{array}{l}\text { Menyajikan konsep dalam berbagai bentuk } \\
\text { representasi matematis } \\
5\end{array}$ & $\begin{array}{l}\text { Mengembangkan syarat perlu atau syarat cukup } \\
\text { dari suatu konsep }\end{array}$ & 30\% \\
6 & $\begin{array}{l}\text { Menggunakan dan memanfaatkan serta } \\
\text { memilih prosedur atau operasi tertentu } \\
\text { Mengaplikasikan konsep algoritma } \\
\text { pemecahan masalah }\end{array}$ & $20 \%$ & \\
\hline
\end{tabular}

Berdasarkan Tabel 1 di atas diketahui bahwa siswa menyatakan ulang konsep dengan kategori cukup sebesar $50 \%$, siswa mengklasifikasi objek menurut sifat tertentu sebagai konsepnya dengan kategori baik sebesar $65 \%$, siswa memberikan contoh dan bukan contoh dari suatu konsep dengan kategori cukup sebesar $60 \%$, siswa menyajikan konsep dalam berbagai bentuk representasi matematis dengan kategori kurang sebesar $40 \%$, siswa mampu mengembangkan syarat 
perlu atau syarat cukup dari suatu konsep dengan kategori kurang sebesar 30\%, siswa menggunakan dan memanfaatkan serta memilih prosedur atau operasi tertentu dengan kategori sangat kurang sebesar 20\% dan siswa mengaplikasikan konsep atau algoritma pada pemecahan masalah dengan kategori kurang sebesar $20 \%$. Skor rata-rata yang diperoleh pada pemahaman konsep sebesar 40,71\%. Hasil tes tersebut menunjukkan bahwa siswa kelas V di SD Negeri Maguwoharjo 1 Yogyakarta belum menguasai indikator pemahaman konsep matematika.

Berdasarkan hasil wawancara dengan guru kelas V SD Negeri Maguwoharjo Yogyakarta, peneliti menemukan beberapa kesulitan mengenai kemampuan pemahaman konsep matematika. Menurut guru kelas V, beragamnya siswa di dalam kelas beragam pula kesulitan dalam pembelajaran matematika. Siswa hanya meniru dan terpaku pada contoh penyelesaian soal sesuai yang guru berikan dan sedikitnya siswa yang mudah memahami dan tidak terpaku pada contoh yang diberikan. Sebagai besar siswa juga selalu membuka buku sebagai pedoman penyelesaian soal dibandingkan dengan siswa yang sudah hafal rumus, serta siswa masih bingung dalam pengurutan penyelesaian soal antara penjumlahan, pengurangan, pembagian dan perkalian. Kesulitan yang dialami siswa menurut guru, berdasarkan indikator mengembangkan syarat perlu atau syarat cukup, menggunakan dan memanfaatkan operasi tertentu dan mengaplikasikan konsep atau algoritma pada pemecahan masalah.

Hasil wawancara dengan siswa kelas V, kesulitan yang dialami dalam pembelajaran matematika sesuai dengan yang dikatakan oleh guru kelas V. Kesulitan siswa beragam, ada yang mengatakan sulit dalam memberikan contoh dari suatu konsep dan sulit dalam menyelesaikan soal sesuai dengan prosedur atau operasi matematika. Terlebih jika soal tersebut dalam bentuk soal cerita. Namun kesulitan siswa lebih condong pada penggunaan prosedur atau operasi matematika dan konsep algoritma. Diperoleh hasil wawancara memperlihatkan sebagian besar siswa belum menguasai pembelajaran matematika serta kurangnya kesadaran diri pada siswa akan pentingnya matematika dalam kehidupan.

Kesulitan yang dialami oleh siswa kelas V saat pembelajaran matematika bukan sekedar sulit dalam pemecahan masalah. Tetapi kesulitan tersebut terdapat pada indikator kesulitan konsep matematika yang meliputi (1) kesulitan dalam memilih rumus untuk pemecahan adalah, (2) siswa tidak sesuai dalam menggunakan rumus dengan kondisi prasyarat berlakunya rumus atau tidak mencantumkan rumus (Nym, Darjiani, Meter, Agung, \& Negara, 2015), sehingga banyak siswa yang menghiraukan dalam menyelesaikan persoalan matematika dengan tidak menuliskan rumus dengan baik dan sesuai pada materi yang akan dipecahkan serta penggunaan rumus yang tidak sesuai dengan berlakunya rumus pada soal tersebut.

Piaget mengatakan bahwa "Anak dilahirkan dengan beberapa kemampuan sensorimotor yang memberi kerangka bagi interaksi awal lingkungan anak tinggal. Tapi bagi Piaget sendiri, sensorimotor adalah proses yang lamban karena skemata baru terus menerus berkembang dari skemata sebelumnya. Skemata ini menunjukkan bahwa pertumbuhan intelektual diawali dengan tanggapan refleksif anak pada lingkungan akan selalu berkembang hingga mencapai titik dimana anak dapat berpikir peristiwa yang memungkinkan dan mampu secara mental untuk bereksplorasi kemungkinan akibatnya" (Fatimah, 2015). Hal inilah yang menjadi kendala siswa usia dasar dalam memenuhi indikator pemahaman konsep matematika.

Pemahaman konsep lebih penting dibandingkan dengan menghafal, oleh karena itu tidak boleh salah dalam 
menyampaikan arahan kepada siwa jika tidak maka konsep tidak dapat dipahami (Fahrudin, Zuliana, \& Bintoro, 2018). Empat faktor menurut Piaget (Shadiq \& Mustajab, 2011) yang memiliki pengaruh pada perkembangan kognitif, yaitu: (1) Kematangan (naturation) otak dan sistem syarafnya, (2) Pengalaman (experience) yang terdiri atas fisik dan logika-matematis,

(3) Transmisi sosial, dan

Penyeimbangan (equilibration).

Terdapat cara yang mendalam untuk menstimulus pemulihan bagi siswa usia dasar yang merasa kesulitan dalam pemahaman konsep matematika dan berpengaruh pada perkembangan kognitifnya. Cara-cara tersebut adalah sebagai berikut (Yeni \& Almuslim, 2015): (1) Metode teritorial yaitu, metode yang membutuhkan pendamping berkompeten yang mempunyai keahlian khusus untuk siswa yang kesulitan belajar matematika. cara yang biasa digunakan adalah berhitung menggunakan tangan, (2) Metode visual yaitu, mengawali hal yang nyata ke yang abstrak. Pembagian gambar yang tidak menyertakan angka dibarengi bicara untuk menjelaskan gambar, dan (3) Mempersiapkan untuk latihan dan mengulangi.

Berdasarkan analisis dengan menggunakan indikator pemahaman konsep matematika siswa, penanaman konsep perlu dikembangkan sejak sekolah dasar. Pentingnya pembelajaran matematika bagi siswa usia dasar perlu dikembangkan, terutama dalam kemampuan pemahaman konsep sehingga dapat menyelesaikan pemecahan masalah. Melalui penataan nalar, keaktifan siswa dan kemandirian dalam proses pembelajaran matematika maka akan membantu perkembangan kognitif siswa.

\section{KESIMPULAN}

Perkembangan kognitif siswa usia dasar adalah bagian dari aspek yang penting untuk dipahami, terutama pada pendidikan khususnya kegiatan belajar mengajar. Kemampuan dan perkembangan kognitif siswa usia dasar berbeda-beda setiap tingkatan usia dan persoalannya. Rentang usia siswa sekolah dasar yaitu 7-12 tahun dimana anak sudah bisa berpikir logis, rasional, ilmiah dan objektif terhadap sesuatu yang bersifat konkret. Karena perkembangan kognitif memberikan pengaruh yang besar terhadap kemampuan emosional, mental dan berbahasa. Pada fase ini dalam proses pembelajaran, guru harus menyampaikan materi yang sifatnya empirik dan bukan abstrak. Pembelajaran matematika memiliki indikator pemahaman konsep yang posisinya sangat penting dalam menyelesaikan persoalan matematika dan kehidupan sehari-hari.

Berdasarkan hasil observasi yang telah dilaksanakan, siswa masih banyak yang belum menguasai keseluruhan indikator pemahaman konsep matematika. Siswa kebingungan dalam menyelesaikan soal yang diberikan guru dan berdasarkan hasil tes diketahui bahwa pemahaman konsep matematika siswa masih rendah. Hasil wawancara dari guru dan siswa dalam pelaksanaan pembelajaran matematika, hanya beberapa indikator saja yang dapat dikuasai diantaranya menyatakan ulang sebuah konsep, mengklasifikasi objek sesuai dengan sifatnya dan memberi contoh dan bukan contoh dari suatu konsep. Maka solusi yang diterapkan oleh guru adalah memberikan beberapa metode yang tepat untuk mencegah dan mengurangi kesulitan belajar anak dalam pemahaman konsep matematika dan meningkatkan perkembangan kognitif.

\section{DAFTAR PUSTAKA}

Astuti, S. D. (2012). Upaya Peningkatan Motivasi Dan Hasil Belajar Matematika Siswa Melalui Metode Pembelajaran Edutainment (Education Entertainment) Siswa Kelas IV SD Negeri 2 Karangnongko Boyolali Tahun Ajaran 2011/2012. Skripsi. UMS. (tidak diterbitkan)

Bujuri, D. A. (2018). Analisis Perkembangan Kognitif Anak Usia 
Dasar dan Implikasinya dalam Kegiatan Belajar Mengajar. LITERASI (Jurnal Ilmu Pendidikan), $\quad 9(1), \quad 37$. https://doi.org/10.21927/literasi.20 18.9(1).37-50

Fahrudin, A. G., Zuliana, E., \& Bintoro, H. S. (2018). Peningkatan Pemahaman Konsep Matematika Melalui Realistic Mathematic Education Berbantu Alat Peraga Bongpas. ANARGYA: Jurnal Ilmiah Pendidikan Matematika, 1(1). https://doi.org/10.24176/anargya.v1 i1. 2280

Fathani, A. H. (2009). Matematika Hakikat dan Logika. Yogyakarta: Ar-Ruzz Media

Fatimah, I. (2015). Perkembangan Kognitif: Teori Jean Piaget. Jurnal Intelektualita, 3(1), 27-38.

Gunawan, I., \& Palupi, A. R. (2017). Taksonomi Bloom - Revisi Ranah Kognitif: Kerangka Landasan Untuk Pembelajaran, Pengajaran, dan Penilaian. E-Journal.Unipma, $7(1)$,

98-117. https://doi.org/http://doi.org/10.252 73/pe.v2i02.50

Hidayati, K. (2012). Pembelajaran Matematika Usia SD/MI Menurut Teori Belajar Piaget. Jurnal Cendekia Vol 10 (2). Pp. 291-308. https://doi.org/10.21154/cendekia.v $10 \mathrm{i} 2.417$

Latifa, U. (2017). Aspek Perkembangan pada Anak Sekolah Dasar : Masalah dan Perkembangannya. Journal of Multidisciplinary Studies, 1(2), 185-196.

Lestari, I. (2018). Pengembangan Bahan Ajar Matematika Dengan (Development of Mathematics Teaching Material Using. GAUSS: Jurnal Pendidikan Matematika, 01(01), 26-36.

Nym, N., Darjiani, Y., Meter, I. G., Agung, I. G., \& Negara, O. (2015). Analisis Kesulitan-Kesulitan Belajar
Matematika Siswa Kelas V Dalam Implementasi Kurikulum 2013 Di Sd Piloting Se-Kabupaten Gianyar Tahun Pelajaran 2014 / 2015 EJournal PGSD Universitas Pendidikan Ganesha, 3(1), 1-11.

Prabowo, C. A., \& Widodo, W. (2018). Mengukur Tingkat Perkembangan Kognitif Siswa Sekolah Dasar dalam Bidang Sains menggunakan Tes Kemampuan Penalaran Ilmiah Determining Elementary Students, Cognitive Development Levels in Science Using Scientific Reasoning Skills Test. 15(2004).

Putri, A. P., Nursalam, N., \& Sulasteri, S. (2014). Pengaruh Penguasaan Materi Prasyarat Terhadap Hasil Belajar Matematika Siswa Kelas Viii Smpn 1 Sinjai Timur. MaPan: Jurnal Matematika Dan Pembelajaran, 2(1), 17-30. Retrieved from http://journal.uinalauddin.ac.id/index.php/Mapan/art icle/view/2718/2976

Rakhmawati, E. (2015). Perbedaan Kemandirian Anak Usia 5-6 Tahun Ditinjau Dari Subyek Pengasuh (Orangtua dan Grandparent) Di TK Kartini 1 Dan TK Kartini 2 Wonoketingal Kecamatan Karanganyar Kabupaten Demak. Skripsi. Jawa Tengah: Universitas Negeri Semarang.

Shadiq, F., \& Mustajab, N. A. (2011). Penerapan Teori Belajar dalam Pembelajaran Matematika di SD. In A. Dhoruri (Ed.). Yogyakarta: P4TK Yogyakarta.

Woolfolk, A. E. (1995). Educational Psychology. USA: Allyn and Bacon.

Yeni, E. M., \& Almuslim, U. (2015). Kesulitan Belajar Matematika Di Sekolah Dasar. Jurnal Pendidikan Dasar (JUPENDAS), 2(2), 1-10. Retrieved from http://jfkip.umuslim.ac.id/index.ph p/jupendas/article/view/ 